\title{
Defining the Iraq-Afghanistan Veteran in American Newspapers
}

\section{Douglas Wilbura}

\begin{abstract}
Employing inductive framing analysis and Entman's theory of framing, this project examines how the U.S. mainstream media defined Iraq-Afghanistan Veterans and their problems. This study used inductive framing analysis with a sample of 180 articles from seven major newspapers and two wire services. The findings revealed five dominant frames: broken veteran, disoriented veteran, fighting the bureaucratic enemy, overwhelmed family, and the financial hardship frames. Two counter-frames that attempted to challenge the dominant frames were identified: moral obligation to help and the healing counter-frames. The finding of this research indicates that while news frames of Iraq-Afghanistan Veterans skew negative, these news frames are not as negative as one might suspect. Thus, veterans' groups, government agencies, and interested political actors need to sponsor counter-frames that emphasize the stability and employability of these veterans.
\end{abstract}

\section{Keywords}

Inductive framing analysis, combat veterans, public relations

Former Iraq Veteran and police officer Christopher Dorner captured national headlines for several days in 2013 when he went on a multi-day shooting spree. His actions cast veterans in a negative light (Goffard, Rubin, and Streeter 2013). Conventional wisdom holds that veterans are portrayed negatively in the news media and in popular culture. Some veterans themselves seem to believe that this negative media coverage is harming their lives (Bouvard 2012). Research shows that news frames can have an effect on public opinion (Lecheler and de Vreese 2012). If conventional wisdom is correct and veterans are framed negatively, then the public's attitude about them might also be negative. This could translate into various forms of discrimination.

The primary purpose of this study is to determine how Iraq and Afghanistan Veterans, no longer in combat, are actually framed in U.S. newspapers. The findings of this study could be used to inform public relations activities of veterans groups and government agencies tasked with assisting veterans. It might also identify a need to develop and sponsor new and more productive counter-frames. It might also serve to help scholars and practitioners develop theoretical approaches and clinical methods to assist veteran in re-integration.

\section{AMERICAN VETERANS AND SOCIETY}

As the war in Afghanistan winds down, over two million military veterans are re-integrating back into civilian society. The operational definition of a veteran is a person who was previously a uniformed member of any branch of the U.S. military.

aThe University of Missouri-Columbia, Columbia, Missouri, USA

Correspondent Author:

Douglas Wilbur, 115 Orr St. Columbia, Missouri 65201, USA 
Re-integration is the process whereby a service member re-adjusts from combat to life as a civilian (Department of Veterans Affairs [V.A.] 2010). According to the U.S. Veteran's Administration, around $13.8 \%$ of Iraq and Afghanistan Veterans have PTSD (post-traumatic stress disorder) (Gradus 2014). In 2015, the unemployment rate of Iraq and Afghanistan Veterans was $5.8 \%$ as compared to civilians at 5.3\% (Bureau of Labor Statistics [BLS] 2016). The suicide rate amongst veterans under the age of 30 jumped by 44\% between 2009 and 2011 (Nicks 2014), and veterans also comprise up to $9 \%$ of the U.S. homeless population (Santos 2014). Thus, veterans as a group are in need of their communities' support in their efforts to reintegrate into civilian life. Despite the numerous problems Iraq and Afghanistan Veterans face, the American public respects its veterans and wants them to be reintegrated into society (Pew Research Center 2011). How the nation reintegrates its veterans is impacted by news coverage of veterans and their problems. Media frames about veterans will impact how the public perceives their employability and mental stability.

\section{THEORETICAL FRAMEWORK AND LITERATURE REVIEW}

This research project uses the theoretical framework of framing analysis, which explains how reality and meanings are constructed through communication. Framing involves the process of selection and salience. Some aspects of a perceived reality are selected and made more salient in a communicating text in such a way as to promote a particular problem definition, causal interpretation, moral evaluation, and treatment recommendation from the vast pool of daily occurrences (Entman 1993). Frames determine what is selected, what is excluded, and what is emphasized in a text (Gamson 1985). They are persistent patterns of cognition, interpretation, and presentation of selection, emphasis, and exclusion. Frames may become self-reinforcing, shaping future direction of news coverage (Gitlin 1980). Frames are an indelible part of the culture from which they have emerged. Because frames are culturally derived, their usage appears to be normal and is often taken for granted (Van Gorp and Vercruysse 2012). Since the U.S. military is a product of American society and culture, frames about its veterans will reflect certain shared cultural assumptions.

Frames are often compiled into a package, which is a cluster of organizing devices that function as an identity kit for a frame. There are three levels of framing: the manifest framing devices, the manifest or latent reasoning devices, and an implicit cultural phenomenon that displays the package as a whole (Van Gorp and Vercruysse 2012). Gamson and Modigliani (1989) specified three determinants of a frame's success. The first is cultural resonance, where the frame resonates with the larger themes of a certain culture. The second is the extent to which a frame's sponsor supports it. The third factor is the professional practices that journalists use to create the news. Power and ideology exert a profound influence over frames, since a society's elites will often sponsor frames (Gitlin 1980).

Frame sponsors create news frames or leverage existing ones to advance their interests and legitimize their power structures. Elites can suppress competing frames sponsored by other elites and less powerful groups (Reese 2001). Frame sponsors suppress competitors through a variety of mechanisms. The sponsors can co-opt frames created by challengers, thereby negating the threat posed by the challengers. Veteran groups present an obvious frame sponsor, but other sponsors with a stake in veteran's issues might exist. Given that some types of frames exist about U.S. military veterans, the following research questions are posed based upon the Entman's (1993) theory of framing.

RQ (Research Question) 1: How did the U.S. mainstream newspapers define the Iraq-Afghanistan Veteran? 
RQ 2: How did the U.S. mainstream newspapers diagnose the causes of the problems faced by the Iraq-Afghanistan Veteran?

\section{FRAMING VETERANS}

Numerous scholarly studies have been conducted on media framing of the wars in Iraq and Afghanistan. However, there is a lacuna of scholarly work analyzing how Iraq-Afghanistan Veterans are portrayed in mass media. McClancy (2013) found that entertainment programing created an image of the Vietnam Veteran as a deranged psychopath. This image was contrasted with the heroic portrayal of World War II (WWII) Veterans. Smith (1973) found that film portrayals of Vietnam Veterans cast them as restless and unable to find peace at home after the horror of war. These portrayals, which were contemporary at the time, reflected the Vietnam Veteran's struggle to reintegrate. Adams (1977) found that veterans who fought in Vietnam believed that news coverage of the war unfair compared to veterans who were not in Vietnam. In contrast, Patterson III (1982) found that the news media provided the Vietnam Veteran with favorable coverage during that war. Media portrayals of disabled veterans are also fraught with stereotypes. Kanyusik (2012) discussed how disabled male veterans were emasculated in the 1946 film, The Best Years of Our Lives. Farnall and Smith (1999) found that media portrayals of disabled people, including veterans, partially encouraged discriminatory beliefs amongst study participants. Thus, given the currently limited research on veteran portrayals, how do the media frame the Iraq-Afghanistan Veterans?

RQ 3: What moral judgments did the U.S. mainstream newspapers make about the Iraq-Afghanistan Veteran and their problems?

RQ 4: What remedies did the U.S. mainstream newspapers suggest to resolve the problems faced by Iraq-Afghanistan Veteran?

\section{METHODS}

The sample was composed of seven major U.S. newspapers and three small circulation local newspapers from towns with large military installations. The major newspapers reviewed were: The New York Times, Chicago Tribune, Washington Post, The Los Angeles Times, Wall Street Journal, The Atlanta Journal-Constitution, and The Dallas Morning News. The newspapers were selected because they have staff reporters who create original reports and they represent different regions of the country. Additionally, two wire services, Reuters and The Associated Press, were selected. These newspapers and wire services are major sources of information among national and regional elites (Cose 1989). The local papers analyzed were: The Killeen Daily Herald adjacent to Fort Hood, Texas, The Columbus Ledger-Enquirer adjacent to Ft. Benning, and The Watertown Daily Times adjacent to Ft. Drum, New York. These newspapers serve communities with a substantial number of veterans and might frame veterans differently than larger papers. The unit of analysis was the entire news story. Only articles that discussed a specific veteran or group of veterans were selected. Only news text including the headings and the body were analyzed; pictures and captions were not analyzed.

Most of the articles were culled directly from the website of the respective newspaper or wire service. A LexisNexis search was also employed to identify any articles that might have been missed through a search of the paper's website. The search terms employed included: military veterans, Iraq War, Afghanistan War, Post Traumatic Stress Disorder, Traumatic Brian Injury, combat veterans, veteran employment, and veteran healthcare. A three-year time frame, from 2011 to 2013, was selected, because the study is primarily concerned about current policy and social implications for veterans undergoing re-integration back into civilian life. A total of 180 news articles were selected. 
Five articles were randomly selected from each newspaper and wire service for each year from 2011 to 2013. Online stories were selected because they are usually lengthier and have more information than printed and broadcast news, which are shortened due to time and space limitations. Only articles about Iraq and Afghanistan Veterans were analyzed, since they are the primary group of veterans currently undergoing re-integration. Articles from all sections of the paper were selected since many of the stories about veterans were written as human-interest pieces and published in the weekend or lifestyle sections. Assigning each candidate article a number and placing these numbers onto strips of paper, which were then blindly selected from a container achieved random selection.

\section{INDUCTIVE FRAMING ANALYSIS AND CODING PROCEDURES}

This study employs an inductive framing analysis method that seeks to identify interpretive frame packages present in a news text. Due to the goal of assisting public relations activities of veteran's groups, an inductive approach is ideal because the frames are allowed to emerge from the data. Using predetermined coding categories, like human conflict frame, might cause much of the nuance within the text to be dismissed. These packages are composed of a core frame, framing devices, and reasoning devices. The core frame is a value or archetype defining the frame. The framing devices are manifested through the presence or absence of certain keywords, stock phrases, stereotyped images, quotations, sources of information, and sentences. Reasoning devices will manifest as casual reasoning about veteran's issues (Van Gorp and Vercruysse 2012).

A three-step coding process was used to analyze framing and reasoning devices. The news text was coded line by line. First, an open coding system was used, whereby recurrent key terms, metaphors, and quotations shared amongst five or more articles were assigned a code. For instance, the title on one article selected in The Killeen Daily Herald was titled, "Family Heals Through Wounded Warrior Ski Trip" (Lozano 2013). This title was assigned a code of hope through healing. The second phase used axial coding where all of the identified codes were listed and reduced to a smaller number of more significant codes (Corbin and Strauss 2008). For instance, the theme of veterans healing from their injuries was present in more than five news texts. Thus, an axial code of healing was created. In the final phase of coding, frame packages were constructed, each with specific framing and reasoning devices assigned. These packages, once assembled, created the frame itself. Only the texts of the news reports were analyzed; images were omitted. One coder was employed for this project, but that was normal for qualitative studies. No preconceived coding categories were developed; rather the coding categories emerged through analysis of the news texts (Charmaz 2006).

\section{FINDINGS}

\section{$R Q$ 1: How Did the U.S. Mainstream Media Define the Iraq-Afghanistan Veteran}

The Iraq-Afghanistan Veteran was framed differently than what common knowledge might prescribe. The veterans were generally not defined as being psychotic or suicidal, except in a few articles. A crazy/suicidal frame exists, and The Dallas Morning News exemplifies this in a quote from a veteran's mother, “...went looking for someone to help her son overcome the demons in his head" (Crawford and Repko 2013, para. 10). However, this frame was uncommon and therefore not a dominant one. The most common frames used to define the Iraq-Afghanistan Veteran were that they were broken and disoriented. This damage was caused by their 
wartime service, not the result of any personal flaws that the veteran might have. This is despite the fact that the majority of these veterans are not seriously disabled, nor do they have PTSD. A typical method of describing these veterans is, "endless medical appointments and ... complicated medical regimes" (Einhorn 2011, para. 9). Thus, the civilian audience might be led to conclude that these veterans are not capable of being fully productive members of their community.

Broken veteran frame. This frame casts the veteran as having been broken by the trauma of war and overwhelmed with physical and psychological injuries. Coverages of veterans with PTSD and traumatic brain injury, which are the "signature wounds" of the wars in Iraq and Afghanistan, often fall into this frame (Torpy 2011, para. 5). A typical description of a veteran in this frame was "He sometimes uses a wheelchair or cane. He suffers seizures. He’s confused and disoriented. He's in and out of the emergency room almost every week. After three combat tours in Iraq, he suffers from PTSD and TBI” (Eiserer 2011, para. 2). The veteran as a victim of war is implied in many stories exhibiting this frame. The empty shell metaphor was a common method of describing returning veterans. Recurring references were made about a young, healthy, and vibrant man going off to war and returning, "like he was an empty shell" (Kristof 2012, para. 5). In this frame, the veteran is like humpty dumpty and cannot be put back together again.

The disoriented veteran frame. Another dominant frame used to define the Iraq-Afghanistan Veteran was the disoriented veteran frame. This frame deals with veterans in general, wounded or not, struggling to reintegrate back into civilian life. Disoriented veterans have been cast out of a military structure, one that provided order and meaning to their lives, and placed into a civilian world that is not prepared to cope with the veterans. An article sums up the frame with a quote from a concerned civilian, "They serve so many tours ... What is it going to be like when they try to integrate into society?” (Henderson and Rigby 2012, para. 10). One common metaphor was that the civilian world is chaos when compared to the structure and discipline of military life. A Wall Street Journal article employs this metaphor perfectly when it portrays, "A generation of veterans is stumbling out of the chaos of war into the chaos of the civilian world. They're moving from a highly disciplined environment where violence is normal into an unstructured environment where violence is prohibited. Many find it is the peace they can't handle” (Philips 2012a, para. 5). This portrayal creates a Rambo-like caricature of the veteran as a dysfunctional and dangerous misfit who will always present a threat to normal people.

\section{RQ 2: How Did the U.S. Mainstream Media Diagnose the Causes of the Problems Faced by the Iraq-Afghanistan Veteran}

The causes of the problems that veterans face were not diagnosed thoroughly. The war was the obvious implied cause of physical and mental wounds. The title of one Wall Street Journal article, "One Taliban Bullet, Two Lives Lost”, nicely summarizes how a Taliban attacker physically killed one veteran and psychologically killed his friend (Philips 2012b). It is implied that participating in combat causes physical and mental anguish, which manifests into drug addiction, suicide, and criminal behavior. However, the war as a cause of veteran issues was not stated throughout the texts. The most interesting finding of this study is that the V.A. and Department of Defense (DOD) bureaucracies were portrayed as being the cause of many veterans' immediate problems. Furthermore, the inability of families to cope with their veterans' personal issues is also a cause of their problems.

Fighting the bureaucratic enemy frame. Interestingly, the dominant frame is that veterans return from the war and must continue fighting against 
a bureaucratic enemy. This enemy is the V.A. and sometimes the DOD, who resists providing the veteran with services they are entitled to. A New York Times piece stated, "One of the most frustrating aspects of life now, they say, is the bureaucracy they face at the Department of Defense and Department of Veterans Affairs" (Einhorn 2011, para. 10). This treatment was rather mild when compared to several reports that quoted a U.S. Ninth Circuit Court of Appeals ruling on the V.A.'s “unchecked incompetence” (Glantz 2011, para. 8). One common metaphor was "hurdles", implying that veterans and their families had to jump through a never-ending series of hurdles to access services they were entitled to receive (Marcus 2013, para. 3). Family members of disabled veterans have to become "navigators" and lead their loved ones through the byzantine mess that is the Veteran's Administration (Einhorn 2011, para. 10).

Overwhelmed family frame. The inability of the veterans' families to cope with their own internal problems is another factor contributing to those problems faced dealing with bureaucracies. Families are not held as guilty of any moral or legal error, they are just overwhelmed and unable to function effectively. The families of disabled veterans were also cast as having been a casualty of the wars in Iraq and Afghanistan. The stories acknowledge that the suffering of the families is often as potent as that of the veterans. An article by The Dallas Morning News described this by stating, "The legacy of 9/11 on military families is a decade of unremitting deployments that have taken an emotional and psychological toll” (Tarrant 2011, para. 16). The war back home was another common metaphor to describe how soldiers fight a war overseas, and when he or she returned, the veteran and their family must fight another war back home. A veteran's wife was quoted as saying, "I'm supposed to be able to fix him, but I can't. They fight a war over there, and then they have to fight a war when they come back” (Booke 2012, para. 22). This frame has interesting implications since veterans' benefits programs are mostly designed to aid the veteran themselves. Little aid is offered to a disabled veteran's family by the government or private charities. The sacrifices that family members make in caring for the veteran would often be unknown to the public if not for this frame. To sum up this situation, a family member of one veteran expressed, "My home has been a nightmare" (Kristof 2012, para. 14).

\section{$R Q$ 3: What Moral Judgments Did the U.S. Mainstream Media Make About the Iraq-Afghanistan Veteran and Their Problems}

The articles failed to thoroughly examine the moral aspects of the issues facing Iraq-Afghanistan Veterans. For the most part, the journalists refrained from making moral judgments about these veterans, even those engaging in criminal behavior. Two articles did examine the issues of guilt that selected veterans faced due to their combat operations. One article quoted a former Marine Captain as saying, "I can’t forgive myself” (Jelinek 2013, para. 2). However, this limited sample does not constitute a frame. The latent reasoning devices seemed to imply that veterans were just hapless victims upon whom the consequences of war were imposed. However, nothing in the text explicitly stated this. The bureaucratic enemy frame did render moral judgments of the V.A. and DOD systems, which clearly failed to serve the needs of veterans. A Chicago Tribune article quoted one leader of a veterans' group as saying, "There quite literally are not enough people that have knowledge of veterans' experiences and who have the professional expertise to provide them the health care that they need" (Cameron 2011, para. 7).

Financial hardship frame. The financial hardship frame was closely related to the bureaucratic enemy, disoriented veteran, and the family as a casualty frames. Problems with processing disability claims combined with unemployment cause financial 
hardships for the veterans and their families. A piece in the Wall Street Journal succinctly summarizes the impact of financial hardships on veterans, as "They live and die in dumpsters or under freeway overpasses" (Tribe and Shriver 2011, para. 3). The title of one article from the Ledger-Enquirer describes how returning veterans face a "less-than-hopeful job market” (Abdullah 2011, title). The families of disabled veterans are also impacted as, "Families go through savings and older parents dip into retirement funds" in order to care for their loved ones (Einhorn 2011, para. 5). Financial instability impacts female veterans with children even more harshly. As one female veteran revealed, "It's frustrating and depressing because I want stability for my kids, and I really can’t provide that” (Zavis 2013, para. 39).

RQ 4: What Remedies Did the U.S. Mainstream Media Suggest to Resolve the Problems Faced by Iraq-Afghanistan Veteran

The obvious remedy is for the government to dramatically improve the delivery of services to the veterans and service members still serving in the military. A quote from one army psychologist exemplifies this as, "He regarded the Army's view of mental health as a second-class problem that can be minimized or overlooked during deployment" (Cohen 2013, para. 22). However, there were too few framing devices to say that this constituted a separate frame. Thus, two dominant frames suggested remedies to the audience. First was the moral obligation to help frame, followed by the healing frame. However, the most telling aspects of the frame packages are what common sense remedies they failed to discuss. The frames indicted the V.A. and the DOD, but they ignored the role of the political elites who are responsible for the performance of these government institutions. They also failed to address the role of the economic elites who manage corporations, which could hire veterans. The news reports also failed to discuss the gains made in helping veterans re-adjust through reforms of the V.A. and companies that have made significant commitments to hire veterans. Finally, the news reports omitted discussion of how veterans' issues might be managed in future conflicts.

Moral obligation to help frame. The moral obligation to help veterans frame indirectly challenges the civilian audience to help veterans. However, this frame was not explicitly proscriptive in how the audience should help veterans. A New York Times article epitomizes this frame with the following quote, "These are people whom we put in harm's way, and we have a moral obligation to help them" (Frosch 2011, para. 4). This frame views veterans as being at least partially helpless against external forces impeding their recovery. One metaphor that was present asserted that civilians must "stand behind veterans" after they stood up for the nation during wartime. A quote from retired Army General Barry McCaffrey says, "We've got this battle force that kept us safe since 9/11: now we've got to stay behind them” (Henneberger 2013, para. 12). A Los Angeles Times article used a quote about civilian employers' states, "I think employers want to be part of the solution, but they are not sure how to do that” (Zavis 2012, para. 13). One Washington Post article discussed how, "Dropping the word disorder in favor of injury will reduce the stigma” (Jaffe 2012, para. 4).

Healing frame. The healing frame invites the audience to perceive veterans as being in the process of healing. This frame passively acknowledges that many veterans do have serious health and social issues. However, it appears to mitigate the effects of the broken and disoriented veteran frames. The healing frame essentially states that while veterans have problems, they can, and do eventually heal. A recovering veteran was described as, "He has abstained from drinking since his arrest... He has ups and downs, but on most days, he sees some possibility of a future” (Goode 2011, para. 72). Another veteran who benefited from a music program stated, "The day she started recovering from PTSD is the same day she 
stopped and listened to the music" (Ritzel 2013, para. 1). The title of one article from the Watertown Daily Times was, "Veterans Find Peace" (Beckstead 2013, title). Thus, no problem is insurmountable for injured and troubled veterans. Therefore, they should be forgiven for most forms of abnormal behavior and offered acceptance.

\section{CONCLUSIONS}

Employing inductive framing analysis techniques borrowed from Van Gorp and Vercruysse (2012) that incorporates Entman's (1993) theory of framing, this research identified frames used to define Iraq-Afghanistan Veterans and their problems. The finding of this research indicates that while news frames of Iraq-Afghanistan Veterans skew negative, these news frames are not as negative as one might suspect. While most Iraq-Afghanistan Veterans are psychologically stable and physically healthy, one might never develop an understanding of this based upon news coverage. Thus, veterans' groups, government agencies, and interested political actors need to sponsor counter-frames that emphasize the stability and employability of these veterans. Such action might start to create an environment more conducive to effective veteran reintegration. Interestingly, there were no significant framing differences between the major daily newspapers and the smaller papers adjacent to military installations. Thus, proximity to military personnel and a large veteran population does not seem to have much of an impact upon how journalists frame veterans and their problems.

The media portrayal of disabled veterans does seem to benefit that group. It cannot be denied that a sizable minority of Iraq-Afghanistan Veterans do suffer from serious health and social problems. These veterans do need extensive support from both the public and the government to sustain a decent quality of life. The media's framing of these veterans as victims of an inept bureaucracy is advantageous for veterans' rights activists who advocate for serious institutional reform. The moral obligation to help frame might predispose the audiences to embrace pro-veteran policies and donate to veterans' charities. Veterans' groups and concerned allies can leverage these frames and emphasize the healing frame to advocate for more effective reintegration programs.

Finally, veterans' issues are an inexorable part of war, and preparations should be made to address the aftermath. Combat service always causes injury for some veterans. The government is subsequently morally and legally obligated to care for these veterans. The frame packages discovered in this study lack any serious discussion about the necessity or benefits of sending service members into combat in the first place. The question that whether the human sacrifice made during the global war on terrorism was justified has been heretofore ignored. Additionally, while certain government agencies are held responsible for their failure to provide services, specific political actors who supervise these agencies were not held accountable.

\section{References}

Abdullah, H. 2011. "Veterans, Like Ronald Williams, Return to Less-Than-Hopeful Job Market.” Ledger-Enquirer, June 8. Retrieved (http://www.ledger-enquirer.com/2011/06/08/ 1609932/veterans-like-williams-return.html).

Adams, A. A. 1977. "A Study of Veterans Viewpoints on TV Coverage of the Vietnam War." Journalism Quarterly 54(2): 248 .

Adams, C. 2013. "Millions Went to War in Iraq, Afghanistan, Leaving Many With Lifelong Scars.” McClatchy Newspapers, March 14. Retrieved (http://www.mcclatchydc. com/2013/03/14/185880/millions-went-to-war-in-iraq-afgh anistan.html\#storylink=cpy).

Beckstead, B. 2013. "Veterans Find Peace at Base Camp Serenity Retreat on S. Lawrence River.” Watertown Daily Times, August 11, p. B2.

Booke, E. 2012. "Group Based in Dallas Area Helps War Vets Recover Through Fishing.” Dallas Morning News, May 24. Retrieved (http://www.dallasnews.com/news/local-news/ 20120524-group-based-in-dallas-area-helps-war-vets-recov 
er-through-fishing.ece).

Bouvard, M. G. 2012. The Invisible Wounds of War: Coming Home From Iraq and Afghanistan. New York: Prometheus.

Bureau of Labor Statistics (BLS). 2016. Employment Situation of Veterans Summary. Retrieved (http://www.bls.gov/ news.release/vet.nr0.htm).

Cameron, P. 2011. "Vets Face Shortage of Therapists: New Program Training Clinicians in Psychology of Combat Is an Attempt to Help Fill the Gap.” Chicago Tribune, July 20. Retrieved (http://articles.chicagotribune.com/2011-07-20/ news/ct-x-0720-vets-mental-health-20110720_1_vets-soldi ers-project-combat).

Charmaz, K. 2006. Constructing Grounded Theory: A Practical Guide Through Qualitative Analysis. Los Angeles: Sage.

Cohen, S. 2013. "Vet Who Saved Many in Iraq Couldn’t Escape Demons.” Associated Press, March 16. Retrieved (http://bigstory.ap.org/article/vet-who-saved-many-iraq-cou ldnt-escape-demons-0).

Corbin, J. and A. Strauss. 2008. Basics of Qualitative Research: Techniques and Procedures for Developing Grounded Theory. 3rd ed. Thousand Oaks, CA: Sage.

Cose, E. 1989. The Press. New York: Morrow.

Crawford, S. and M. Repko. 2013. "Pair's Bid to Help Troubled Vet Suspected of Killing Them at Gun Range Doesn't Surprise Acquaintances.” Dallas Morning News, February 9. Retrieved (http://www.dallasnews.com/news/ crime/headlines/20130209-pairs-bid-to-help-troubled-vet-s uspected-of-killing-them-at-gun-range-doesnt-surprise-acqu aintances.ece).

Department of Veterans Affairs. 2010. Returning From the War Zone: A Guide for Families of Military Members. Retrieved (http://www.mentalhealth.va.gov/returning servicevets. asp).

Einhorn, C. 2011. "Looking After the Soldier, Back Home Damaged.” The New York Times, September 27. Retrieved (http://www.nytimes.com/2011/09/28/us/looking-after-thesoldier-back-home-and-damaged.html?pagewanted=all\&_r $=0)$.

Eiserer, T. 2011. "Dallas Vet Struggles With Brain Injury, PTSD, VA Medical System.” Dallas Morning News, August 28. Retrieved (http://www.dallasnews.com/news/ community-News/dallas/headlines/20110828-dallas-vet).

Entman, R. 1993. "Framing: Toward Clarification of a Fractured Paradigm.” Journal of Communication 43(4):51-58.

Farnall, O. and K. A. Smith. 1999. "Reactions to People With Disabilities: Personal Contact Versus Viewing of Specific Media Portrayals.” Journalism \& Mass Communication Quarterly 76(4):659-672.

Frosch, D. 2011. "Marijuana May Be Studied for Combat
Disorder.” The New York Times, July 18. Retrieved (http://www.nytimes.com/2011/07/19/us/19pot.html?_r=0).

Gamson, W. A. 1985. "Goffman's Legacy to Political Sociology.” Theory and Society 14(5):605-622.

Gamson, W. A. and A. Modigliani. 1989. "Media Discourse and Public Opinion on Nuclear Power: A Constructionist Approach.” American Journal of Sociology 95(1):1-37.

Gitlin, T. 1980. The Whole World Is Watching: Mass Media in the Making and Unmaking of the New Left. Berkley, CA: University of California Press.

Glantz, A. 2011. "Troubled Veterans and Early Deaths After Iraq.” The New York Times, May 28. Retrieved (http://www.nytimes.com/2011/05/29/us/29bcveterans.html? pagewanted=all).

Goffard, J., J. Rubin, and K. Streeter. 2013. “A Double Killing, a Vengeful Plan, a Wave of Fear.” Los Angeles Times, December 2013. Retrieved (http://graphics.latimes.com/ christopher-dorner-manhunt/\#chapter-one).

Goode, E. 2011. "Coming Together to Fight for a Troubled Veteran." The New York Times, July 17. Retrieved (http://www.nytimes.com/2011/07/18/us/18vets.html?page wanted=all).

Gradus, J. 2014. "Epidemiology of PTSD.” Department of Veterans Affairs. Retrieved (http://www.ptsd.va.gov/ professional/PTSD-overview/epidemiological-facts-ptsd.as p).

Henderson, P. and B. Rigby. 2012. "U.S. Troops Numb, Uncertain After Afghan Massacre.” Reuters, March 15. Retrieved (http://www.reuters.com/article/2012/03/15/ususa-afghanistan-base-idUSBRE82E0AV20120315).

Henneberger, M. 2013. "Veteran's Court Program Helps Warrior's Battle Addiction, Mental Health Crises." The Washington Post, December 2. Retrieved (http://www. washingtonpost.com/politics/veterans-court-program-helpswarriors-battle-addiction-mental-health-crises/2013/12/02/d 44cf352-5b6c-11e3-bf7e-f567ee61ae21_story.html).

Jaffe, G. 2012. "New Name for PTSD Could Mean Less Stigma." The Washington Post, May 5. Retrieved (http://www.washingtonpost.com/world/national-security/n ew-name-for-ptsd-could-mean-less-stigma/2012/05/05/gIQ AlV8M4T_story.html).

Jelinek, P. 2013. "War Zone Killing: Vets Feel 'Alone’ in Their Guilt.” Associated Press. Retrieved (http://bigstory.ap.org/ article/im-monster-veterans-alone-their-guilt).

Kanyusik, W. 2012. “The Problem of Recognition: The Disabled Male Veteran and Masculinity as Spectacle in William Wyler's The Best Years of Our Lives.” Journal of Literary \& Cultural Disability Studies 6(2):159-174.

Kristof, N. D. 2012. “A Veteran’s Death, the Nation's Shame.” The New York Times, April 4. Retrieved (http://www. nytimes.com/2012/04/15/opinion/sunday/kristof-a-veterans- 
death-the-nations-shame.html?pagewanted=all).

Lecheler, S. and C. H. de Vreese. 2012. "News Framing and Public Opinion: A Mediation Analysis of Framing Effects on Political Attitudes.” Journalism \& Mass Communication Quarterly 89(2):185-204.

Lozano, M. 2013. "Family Heals Through Wounded Warrior Ski Trip.” Killeen Daily Herald, December 11. Retrieved (http://kdhnews.com/fort_hood_herald/homefront/family-he als-through-wounded-warrior-ski-trip/article_55dcf0d8-61e f-11e3-b8a0-0019bb30f31a.html).

Marcus, R. 2013. "Military Benefits Hurdles Add to Victims' Abuse." The Washington Post, October 1. Retrieved (http://www.washingtonpost.com/opinions/ruth-marcus-ano ther-sorry-chapter-to-militarys-handling-of-sexual-abuse/20 13/10/01/a8d3ebf2-2abd-11e3-97a3-ff2758228523_story.ht $\mathrm{ml})$.

McClancy, K. 2013. “The Iconography of Violence: Television, Vietnam, and the Soldier Hero." Film \& History 43(2):50-66.

Nicks, D. 2014. "Suicide Rate Soars Among Young Vets: The Number of Male Veterans Under 30 Ending Their Own Lives Jumps by 44 Percent in Two Years.” Time (online), January 10. Retrieved (http://swampland.time.com/2014/ 01/10/report-suicide-rate-soars-among-young-vets/).

Patterson III, O. 1982. "An Analysis of Coverage of the Vietnam Veteran.” Journalism Quarterly 59(2):308-310.

Pew Research Center. 2011. War and Sacrifice in the Post-9/11 Era: The Military-Civilian Gap. Retrieved (http://www. pewsocialtrends.org/2011/10/05/war-and-sacrifice-in-the-p ost-911-era).

Philips, M. M. 2012a. “Convicted Vets Watch Each Other's Backs to Stay out of Prison.” Wall Street Journal, March 24. Retrieved (http://online.wsj.com/news/articles/SB1000142 4052702303812904577295401873709154).

—. 2012b. "One Taliban Bullet, Two Lives Lost.” Wall Street Journal, May 26. Retrieved (http://online.wsj. com/news/articles/SB100014240527023039781045773619 12843069338).

Reese, S. D. 2001. "Prologue-Framing Public Life: A Bridging Model for Media Research.” Pp. 7-31 in Framing Public Life: Perspectives on Media and Our Understanding of the Social World, edited by S. D. Reese, O. Gandy, and A. Grant. Mahwah, NJ: Lawrence Erlbaum.

Ritzel, R. 2013. “Trio Galilei: Music to Ears of Wounded Veterans Recuperating at Walter Reed.” The Washington Post, December 20. Retrieved (http://www.washingtonpost. com/entertainment/music/trio-galilei-music-to-the-ears-ofwounded-veterans-recuperating-at-walter-reed/2013/12/19/ 84fd1b6e-668f-11e3-997b-9213b17dac97_story.html).

Santos, F. 2014. "Program to End Homelessness Among Veterans Reaches a Milestone in Arizona.” The New York Times, January 15. Retrieved (http://www.nytimes.com /2014/01/16/us/program-to-end-homelessness-among-veter ans-hits-milestone-in-arizona.html?_r=0).

Smith, J. 1973. "Between Vermont and Violence: Film Portraits of Vietnam Veterans.” Film Quarterly 26(4):10-17.

Tarrant, D. 2011. “A Generation of Warriors Responded to 9/11 With Level of Commitment Seldom Seen.” Dallas Morning News, September 5. Retrieved (http://www. dallasnews.com/news/local-news/20110905-a-generation-of -warriors-responded-to-911-with-level-of-commitment-seld om-seen-.ece).

Torpy, B. 2011. "Veterans Regroup After Life Interrupted.” Atlanta Journal Constitution, November 7. Retrieved (http://www.ajc.com/news/news/local/veterans-regroup-afte r-life-interrupted/nQNP7/).

Tribe, L. and B. Shriver. 2011. "Why Wounded Warriors Sleep in Dumpsters; The Government Has Failed Homeless Veterans Suffering From Psychological Trauma.” Wall Street Journal, June 9. Retrieved (http://online.wsj. com/news/articles/SB100014240527023044323045763715 91562510516).

Van Gorp, B. 2005. "Where Is the Frame?: Victims and Intruders in the Belgian Press Coverage of the Asylum Issue." European Journal of Communication 20(4):484-507.

Van Gorp, B. and T. Vercruysse. 2012. "Frames and Counter-Frames Giving Meaning to Dementia: A Framing Analysis of Media Content.” Social Science \& Medicine 74:1274-1281.

Zavis, A. 2012. "Poverty Growing Among L.A. County Veterans, Study Finds.” Los Angeles Times, November 9. Retrieved (http:/latimesblogs.latimes.com/lanow/2012/11/ los-angeles-county-veterans-poverty.html).

- 2013. "Iraq Veterans Find the War at Home Is With Red Tape.” Los Angeles Times, December 20. Retrieved (http://www.latimes.com/local/la-me-c1-1220-veterans-bac klog-20131219-dto01667083.htmlstory\#axzz2twCXUezn).

\section{Bio}

Douglas Wilbur, doctoral student, major in US Army (Retired), School of Journalism, The University of Missouri-Columbia, Columbia, Missouri, USA; research fields: strategic communication and public relations. 